\title{
喉頭に発生した成人型横紋筋腫の一症例
}

\author{
岩 谷直 美·鳥 谷 尚 史·鮫 島 靖 浩 - 湯 本 英二
}

\section{Adult Rhabdomyoma of the Larynx}

\author{
Naomi Iwatani, Takafumi Toriya, Yasuhiro Samejima \\ and Eiji Yumoto
}

Extracardiac rhabdomyoma is rare benign tumor found in soft tissue. The majority of instances of extracardiac rhabdomyoma arise in the head and neck regions. Rhabdomyomas are classified into adult and fetal variants. A case of adult rhabdomyoma occurring in the larynx, which appeared in a 29-year-old lady, was reported. The tumor was removed surgically by the laryngofissure approach. The patient remains free of disease at the present time. The clinicopathological features of the tumor are presented with a review the pertinent literature.

Key words : rhabdomyoma, larynx, laryngofissure, immunocytochemistry

$$
\text { はじめに }
$$

喉頭に良性腫瘍が生じる頻度は悪性腫瘍, ポリープなど に比してはるかに少ない. その中でも上皮由来の乳頭腫が ほとんどを占め, 乳頭腫を除くと喉頭にその他の良性腫瘍 が発生する頻度はきわめて稀である。しかし発生頻度こそ 少ないものの, 発生起源の面から興味のもたれる良性腫瘍 が喉頭に生じることがある.

今回我々は喉頭に発生した横紋筋腫の症例を経験した。 横紋筋腫は結節性硬化症に伴って心臓に発生する心臓横紋 筋腫がよく知られているが，心臓以外の軟部組織に発生す るものはまれである.心蔵外横紋筋腫は, これまで, 頭頸

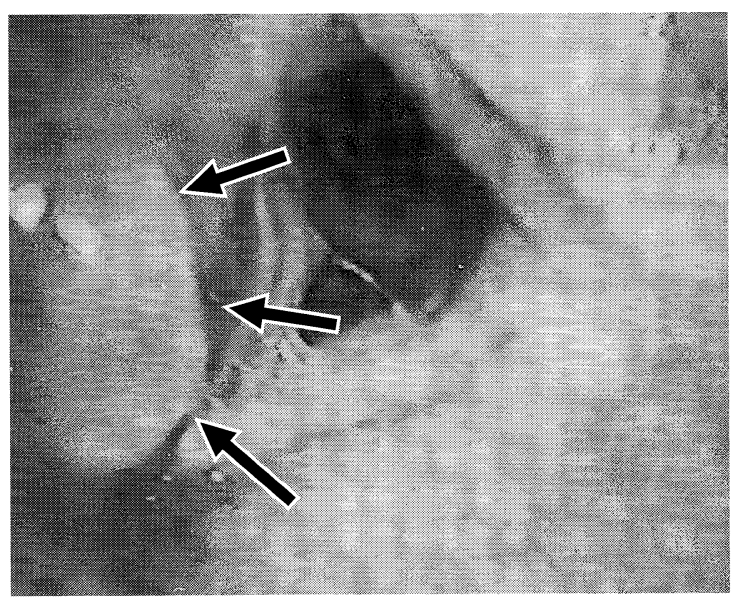

a

図 1 喉頭ファイバースコープ所見 a . 吸気時 b. 発声時 腫瘍（ヶ）により右仮声帯は突出しており発声時には声門間隙（ヶ）を認める.

熊本大学医学部耳鼻咽喉科学教室

Department of Otolaryngology, Kumamoto University たので文献的考察を加えて報告する．

\section{症例}

症例 : 29歳, 女性.

主訴 : 嗄声。

既往歴：10歳時, リウマチ熱に罹患.

家族歴：特記すべき事項なし。

嗜好歴：飲酒歴；なし.

契煙歴；1日10本 $\times 10$ 年間。

b

部, 腋下, 胸壁, 胃, 外陰部などでの発生を報告されてお り，その病理組織像によって成人型と胎児型に分けられて いる。 今回我々は喉頭に発生した成人型横紋筋腫を経験し

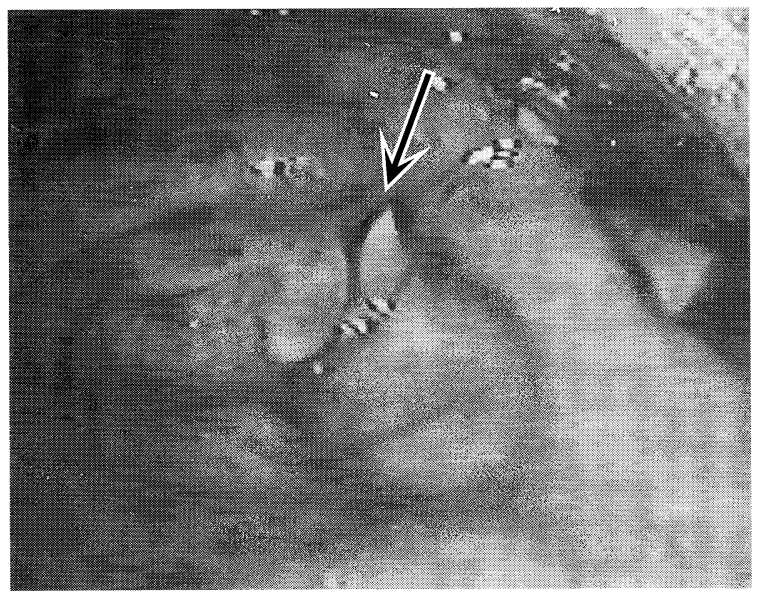




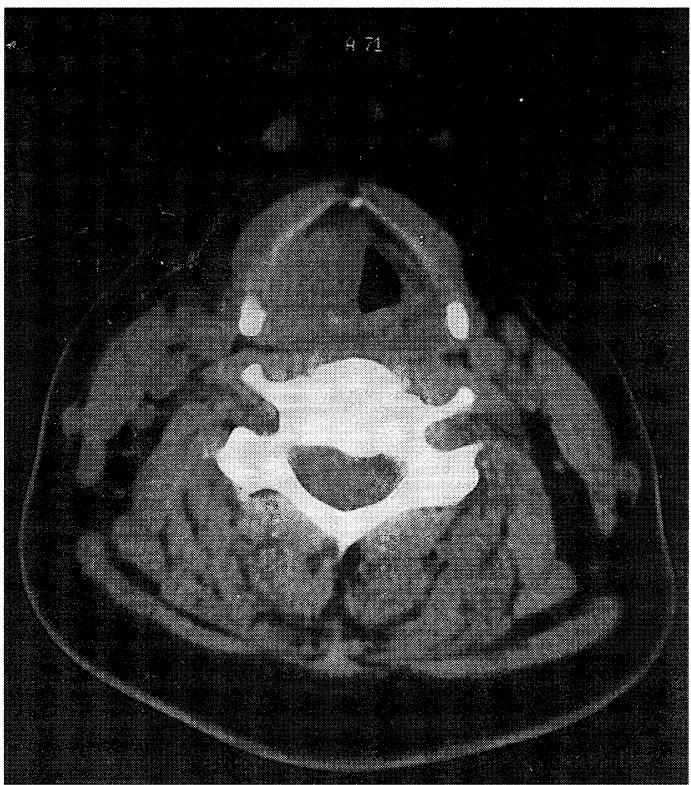

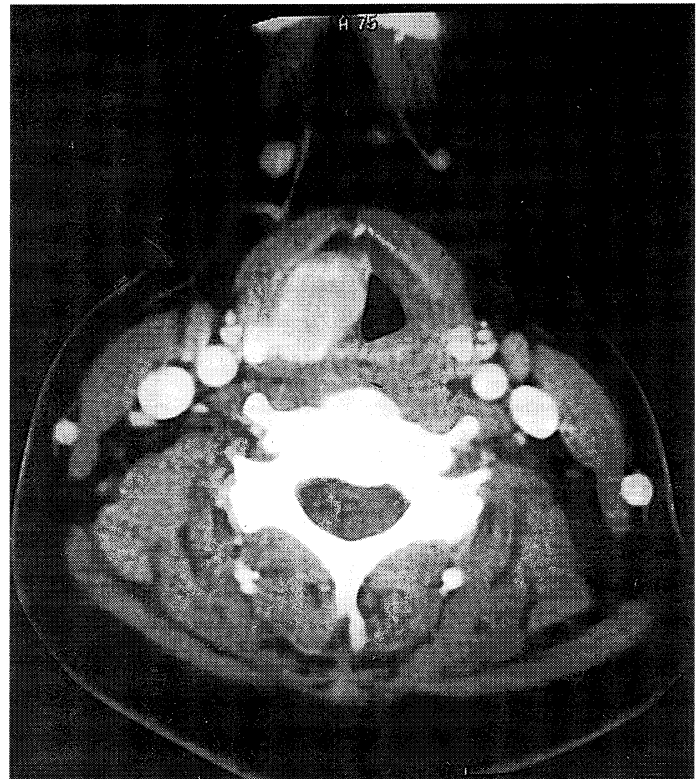

b

図 2 軸位断 CT a. 単純 b. 造影 腫瘍は境界明瞭で均一に造影される。

現病歴：1994年より嗄声を自覚していたが放置していた。 1998年 4 月頃より話すときに咽頭痛が出現し, また嗄声も 増強してきたため, 同年 6 月近医耳鼻咽喉科を受診した。 喉頭ファイバーにて右仮声带の腫張を認め, 保存的加療を 受けていた。しかし症状は改善せず，MRIにて，粘膜下 に腫瘍性病変を認め, 精査加療目的にて同年 9 月 4 日当科 を紹介された。

現症 : 初診時の喉頭内視鏡の所見を図 1 に示寸. 右仮声 带は腫脹しており，粘膜下の腫瘤を疑わせる所見を認めた。 両側声帯の動きは良好であったが，右声帯は腫瘤により圧 排され軽度の变形を認め, 発声時には声門部に間隙を認め た。その他，耳，鼻，咽頭には異常を認めず，頸部リンパ 節の腫脹は触知しなかった。また, 胸部単純 $\mathrm{X}$ 線写真, 血 液検査にても特に異常は認めなかった.

CT 所見 : 右仮声帯部に境界明瞭な径約 $2 \mathrm{~cm}$ 大の楕円 型の腫瘤を認めた。腫瘤は早期に均一に造影された（図2）.

MRI 所見：右仮声带部に声帯レベルから喉頭蓋レベルに かけて T2 強調画像で筋組織よりやや高信号の境界明瞭な 楕円形の腫瘤を認めた（図 3 ). T1 強調画像では低信号を 示し，ガドリニウム造影後の $\mathrm{T} 1$ 強調画像では， CT と同様 に腫瘤はほぼ均一に造影され，またDynamicでは早期に 造影されすみやかに消失しているのが分かった。また，画 像所見から腫瘍の大きさは約 $20 \times 15 \times 25 \mathrm{~mm}$ と考えられた。

経過 : 以上の所見から右仮声帯に発生した血流豊富な良 性の粘膜下腫瘍を疑い, 同年 9 月 24 日喉頭直達鏡下に生検 を行った。顕微鏡下に観察すると粘膜面には異常を認めず, 右仮声帯粘膜にメスにて切開を加えると黄褐色の腫瘍性病 変を認めた，腫瘍はやわらかく，易出血性だった。

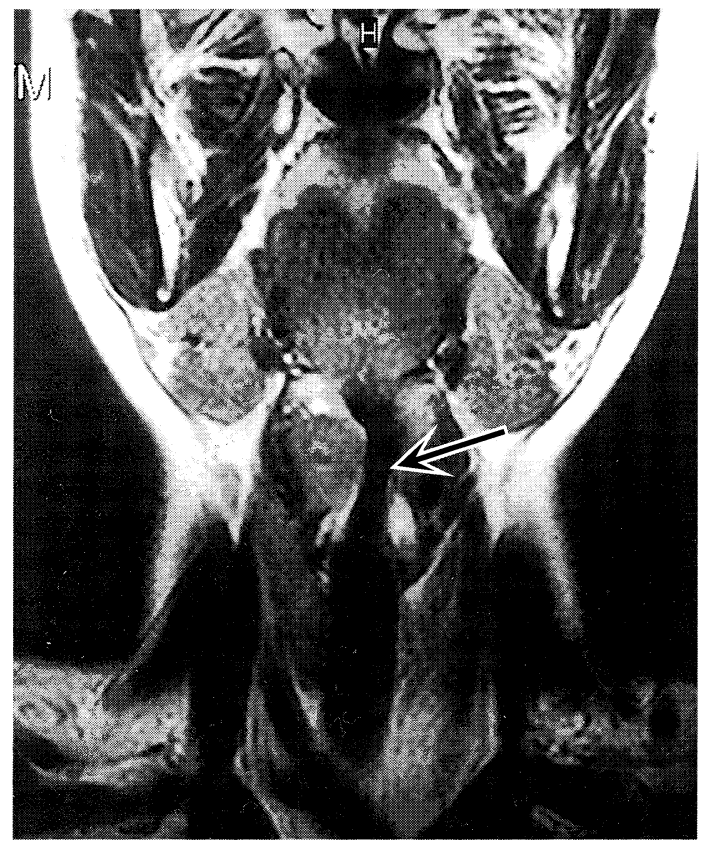

図 3 冠状断 MRI T2 強調像.

その病理組織学的所見を図 4 に示す。

$\mathrm{HE}$ 染色：好酸性の強い顆粒状の細胞質を有する紡錘形 から短紡錘形の腫瘍細胞の充実性増殖を認める。細胞の辺 縁や中心に好酸性が強く腫大した核を認める。この所見か ら横紋筋腫や顆粒細胞腫が疑われた。

PAS 染色：PAS染色にて細胞質はよく染色され，ジア スターゼ消化後 PAS 染色では染色性が消失することよりグ 

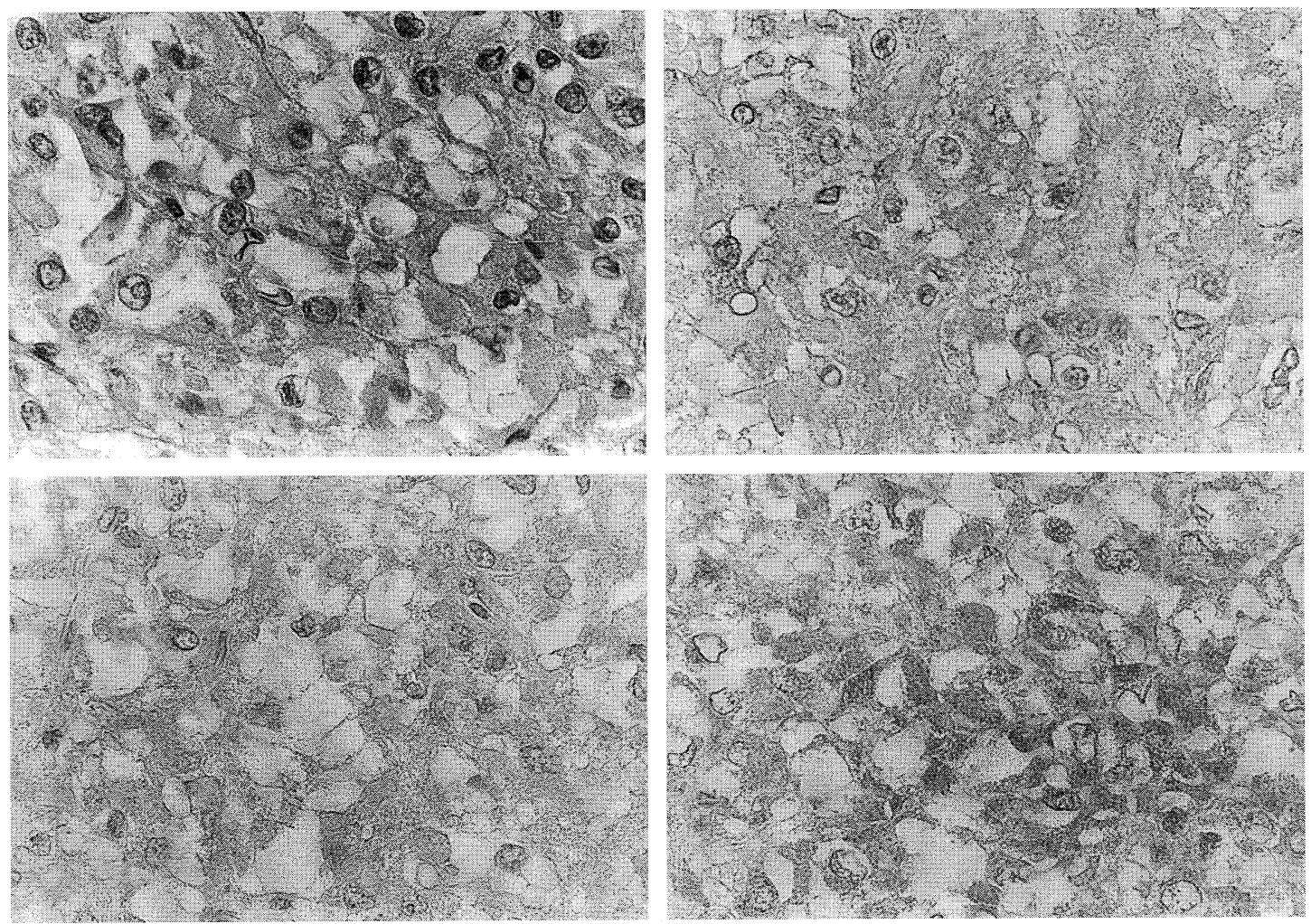

\section{\begin{tabular}{l|l}
$a$ & $b$ \\
\hline$c$ & $d$
\end{tabular}}

図4 病理組織所見 $(\times 400)$

a. HE 染色

b. 免疫染色（抗ミオグロビン抗体）

c. PAS 染色

d. PAS 染色 (ジアスターセ消化後)
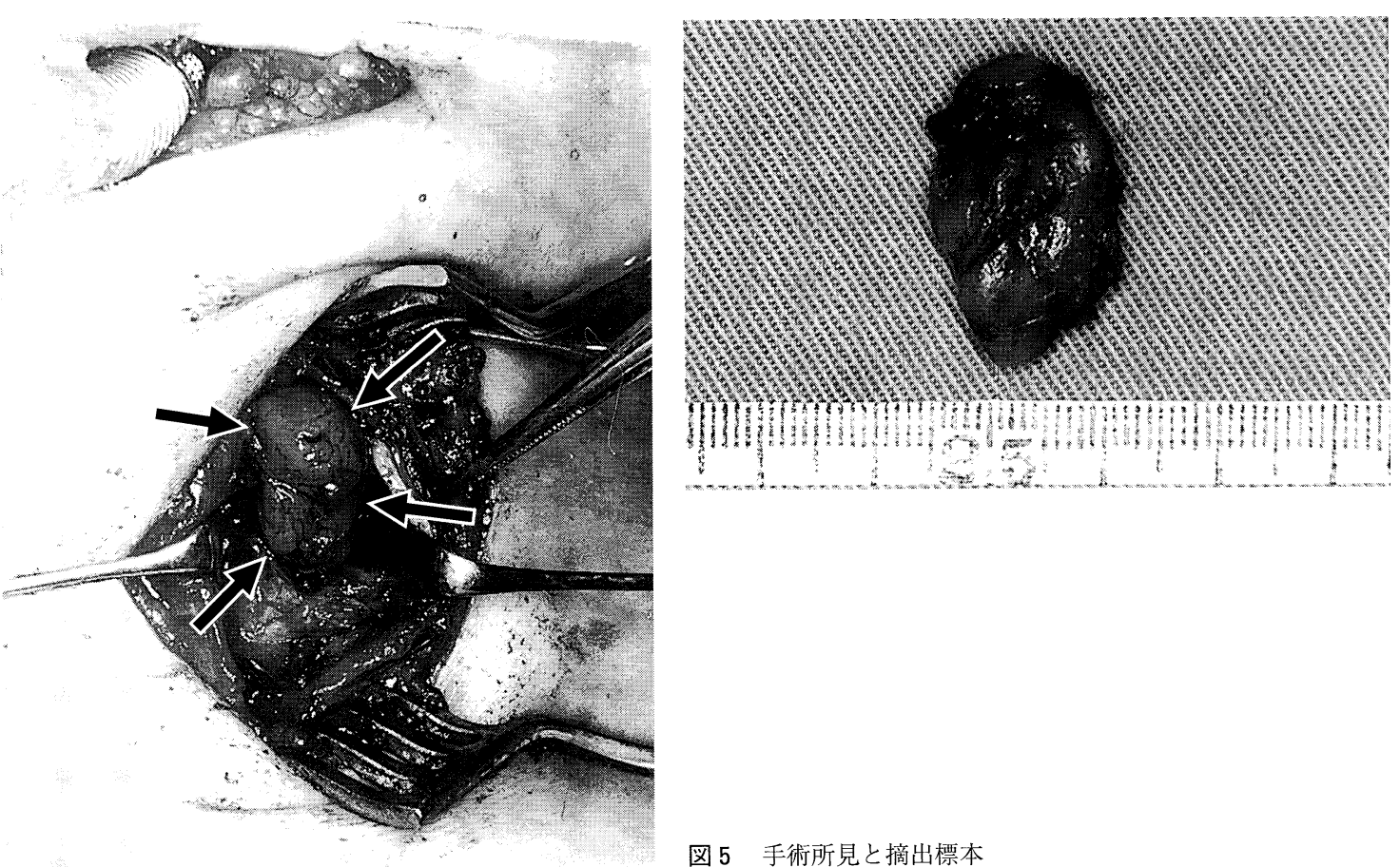

図 5 手術所見と摘出標本

左 : 甲状軟骨, 輪状軟骨に切開を加え甲状披裂筋内に存 在する腫瘍を確認した。

右 : 被膜を有する暗赤色で柔らかい腫瘍であった。 
リコーゲンが胞体内に豊富に存在していることが確認できた.

PTAH (phosphotungstic acid hematoxylin) 染色 : 好酸性の胞体は青色に染まり, 筋原性を示唆する所見であっ た。

免疫染色：腫瘍細胞の胞体は抗 myoglobin 抗体, 抗 desmin 抗体に染色性を示した。

以上の所見から病理組織学的診断にて成人型横紋筋腫と 確定した.

同年10月13日，全身麻酔下に喉頭截開術を施行した。腫 瘍は甲状披裂筋内に存在し被膜を有しており，境界は明瞭 であった．前回生検を行っていたため一部周囲組織との癒 着を認めたが, その癒着した粘膜を含めて腫瘍を全摘出し た（図 5 ). なお，術後の気道確保のために気切口を設けた。 腫瘍の大きさは $19 \times 16 \times 28 \mathrm{~mm}$ ，色調は淡褐色で，軟ら かく, 易出血性の腫瘍であった。

術後，翌日に経口摂食を開始し，11日目に気切口を閉鎖 した. 現在, 外来にて経過観察し 2 年が経過するが, 再発 は認めていない。

\section{考察}

横紋筋腫は骨格筋より発生した良性腫瘍として1864年に 初めてZenkerによって紹介された. 脳の結節性硬化症に ともない心臓に発生する心臓横紋筋腫はよく知られている が, 心臓外横紋筋腫は稀な疾患で骨格筋の良性腫瘍の中で 約 $2 \%$ を占めるとされている1). 心蔵外横紋筋腫はこれまで 頭頸部, 腋下, 胸壁, 胃, 外除部などでの発生を報告され ている. Helliwell らによると1988年までに115例の心臓外 横紋筋腫が報告されており，そのうち頭頸部領域での発生 は87例と約 $76 \%$ を占め, 心臓外横紋筋腫の好発部位である ${ }^{2)}$.

確定診断は病理組織学的検査によって行われ, 組織学的 特徵により成人型および胎児型に分類される。

成人型横紋筋腫は多量の好酸性細顆粒やグリコーゲンの 豊富な細胞質をもつ円形あるいは多角形の腫瘍細胞の増殖 を特徵とする．細胞質はグリコーゲンが流出するため空砲 を形成する。核は核小体が優位の大型胞状で，しばしば偏 在性をもつ.一方，胎児型横紋筋腫の細胞は類円形から紡 錘形を呈し，成人型に比較するとその細胞質は好酸性顆粒 やグリコーゲンにそしいのが特徴である。腫瘍の中央には 未分化間葉系細胞と種々な分化を示す骨格筋細胞よりなる. 特に腫瘍中心部にヒアルロニダーゼに消化されやすい酸性 ムコ多糖類を含有する。

喉頭に発声する稀な良性腫瘍に顆粒細胞腫があるが，そ の組織像は成人型横紋筋腫と非常に似ており, 成人型横紋
筋腫と顆粒細胞腫との鑑別が重要となる. 病理組織診断で は通常の HE 染色に加えて PTHA 染色が行われる. PTHA 染色では筋組織に染色性を示し, 横紋が認められ やすくなる．この染色にて横紋を認めれば横紋筋腫との診 断が得られる. 今回の症例のように $\mathrm{HE}$ 染色, PTHA 染 色にて明らかに横紋を認めない場合，その確定診断には免 疫染色が有効である。desmin は骨格筋，心筋，平滑筋に 分布を認め, myoglobinは横紋筋に分布を認める。 myoglobin が最も横紋筋に特異的であるが, 成人型横紋 筋腫や横紋筋肉腫で陰性となる場合もあり, desminの方 が陽性率としては高い。つまり一般に成人型横紋筋腫は desmin, myoglobin に染色性を示し，顆粒細胞腫は desmin, myoglobin に染色性を示さないことでこれらの 鑑別が可能となる.

我々は，過去の報告をもとに，喉頭に発生した横紋筋腫 についてそれぞれの型の臨床的特徴の検討を行った。喉頭 に発生した横紋筋腫の報告例は成人型，胎児型それぞれ国 内外合わせて28例，12例であった（表 1 )。男女比は両者 ともに男性に多く，それぞれ $19 ： 9 ， 7 ： 5$ で，平均年齢 はそれぞれ52.1歳，46.1歳であった。前田らによると頭頸 部に発生した胎児型横紋筋腫は 3 歳以下の乳幼児での発生 が過半数を占め, その平均年齢は14.3歳と報告されている が3), 喉頭に限っては成人型と胎児型の発生年齢に有意差 は見られなかった。 また主訴は両者ともに嗄声が過半数を 占め, 好発部位は声带および仮声带であり, その臨床像に 相違は見られなかった。

治療は成人型，胎児型ともに摘出で，完全摘出されれば 再発を起こすことはほとんどないとされている，過去の症 例の摘出法は，その発生部位と腫瘍の大きさにより内視鏡 的摘出あるいは頸部の外切開による摘出が選択されていた。

表 1 喉頭に発生した横紋筋腫症例

\begin{tabular}{|c|c|c|}
\hline & 成人型 & 胎児型 \\
\hline 症 例 数 & 28 & 12 \\
\hline 年 齢 & $16 \sim 82(52.1)$ & $23 \sim 78(46.1)$ \\
\hline 男：女 & $19: 9$ & $7: 5$ \\
\hline 主訴 & $\begin{array}{l}\text { 嗄 声 }(16 \text { 例 }) \\
\text { 呼吸困難（7 例 })\end{array}$ & 嗄 声 (6 例) \\
\hline 発生部位 & 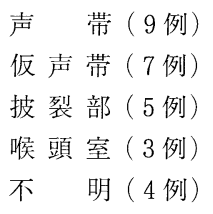 & $\begin{array}{l}\text { 声 } \quad \text { 带 }(7 \text { 例 }) \\
\text { 仮 声帯 }(4 \text { 例 }) \\
\text { 不 } \quad \text { 明 }(1 \text { 例 })\end{array}$ \\
\hline 再発症例 & 3 例 & 1 例 \\
\hline
\end{tabular}

表 2 喉頭に発生した横紋筋腫の再発症例

\begin{tabular}{l|c|c|c|c|c|c}
\hline \hline \multicolumn{1}{c|}{ 報告者(報告年) } & 年齢 & 性別 & 主訴 & 発声部位 & 腫痬の大きさ & 治療 \\
\hline Winther $(1976)^{4)}$ & 39 & 男 & 嗄声 & 声带 & $0.5 \times 0.5 \times 0.5 \mathrm{~cm}$ & 内視鏡的摘出 \\
Modin $(1982)^{5)}$ & 34 & 女 & 嗄声 & 声帯 & 不明 & 内視鏡的摘出 \\
Hamper et al $(1989)^{6)}$ & 51 & 女 & 発声障害 & 披裂喉頭荎譬 & 約 $4 \mathrm{~cm}$ & 咽頭切除術 \\
Zbaren et al $(1996)^{7)}$ & 64 & 男 & 嗄声 & 披裂喉頭蓋襞 & $4 \times 4 \times 5 \mathrm{~cm}$ & 咽頭切除術 \\
\hline
\end{tabular}


しかし 4 例に再発の報告があり（表 2 ），そのうち 2 例は 披裂喉頭蓋譬より発生したもので，その 1 例は 3 回もの再 発が喼められている.よって摘出する際には, 腫瘍の易出 血性も考虑し, 腫瘍の大きさと発生部位により全摘が可能 な適切な摘出法の選択が必要である。また一例は12年後に 再発しており，摘出後も十分な経過観察が必要と思われた。 しかしいずれも悪性に変化した症例の報告はなく，予後は 良好である。

$$
\text { ま と め }
$$

1．喉頭に発生した横紋筋腫の一例を経験した。

2 . 心臟外横紋筋腫は組織学的特徵により成人型および 胎児型に分類されるが, 文献的には, その臨床像に相違は 見られなかった。

3. 過去の報告によると, 横紋筋腫は完全摘出されれば その予後は良好であるが, 再発の可能性もあるため術後の 定期的な経過観察が必要である。

本論文を作成するにあたり，御校閲と御助言をいただい た熊本大学付属病院病理部の猪山賢一教授に心より感謝申 し上げます。

\section{参 考 文 献}

1) J Craig Box et al : Adult rhabdomyoma: presentation as a cervicomediastinal mass. The American Surgeon, 61:271 276, 1995

2) Helliwell et al : Immunochemistry and electron microscopy of head and neck rhabdomyoma. Journal of Clinical Pathology, 41: 1058 1063, 1988

3）前田陽一郎ほか：喉頭に発生した成人型横紋筋腫の 1 症例. 耳鼻咽喉科頭頸部外科, 67：1070 1074, 1995

4) Winther LK : Rhabdomyoma of the hypopharynx and larynx. Journal of Laryngology Otology 90:1041 1051, 1976

5) Modlin B: Rhabdomyoma of the larynx. Laryngoscope $92: 580 \sim 582,1982$

6) Hamper $K$ et al: Rhabdomyoma of the larynx recurring after 12 years: Immunocytochemistry and differntial diagnosis. Archives of Otorhinolaryngology 246:222 226, 1989

7) Zbaren et al : Rare benign neoplasms of the larynx:Rhabdomyoma and lipoma. Journal of Oto-Rhino-Laryngology $224: 351 \sim 355,1995$

8) Imperatori GJ : Rhabdomyoma of the larynx. Laryngoscope 43: 945 948, 1933

9) Climie AWR et al : Rhabdomyoma of the larynx.Archives of Otolaryngology 77 : 409 414, 1963

10) Goldman RL : Multicentric benign rhabdomyoma of skeletal muscle. Cancer 16 : 1609 1613, 1969

11) Battifora HA et al: Rhabdomyoma of the larynx. Cancer $23: 183 \sim 190,1969$

12）森光保ほか：喉頭横紋筋腫の一例. 日本気管食道科 学会会報, $22: 265 \sim 269,1971$

13) Bianchi $\mathrm{C}$ et al : Rhabdomyoma (adult type) of the larynx. Beitraege Zuv Pathologie 156 : 75 79, 1975

14) Ferlito $\mathrm{A}$ and Frugoni $\mathrm{P}$ : Rhabdomyoma purum of the larynx. Journal of Laryngology Otology 89: 1131 1142, 1975

15) Richard A. Bagby et al: Rhabdomyoma of the larynx. Archives of Otolaryngology 102 : 101 103, 1976

16) Boedts $\mathrm{D}$ et al: Adult rhabdomyoma of the larynx. Archives of Otorhinolaryngology 224 : 221 229, 1979

17) Kleinsasser $\mathrm{O}$ et al : Myogenic Tumors of the Larynx. Archives of Otorhinolaryngology $225: 107 \sim 119,1979$

18) Kapadia SB et al : Adult rhabdomyoma of the head and neck: A clonicopathologic and immunophenotypic study. Human Pathology $224: 107 \sim 119,1979$

19) Di Sant'Agnese PA and Knowles DM : Extracardial rhabdomyoma: a clinicopathologic study and review of the literature. Cancer 46: 780 789, 1980

20) Neiville BW et al : Multifocal adult rhabdomyoma:a case and review of literature. Archives of Otolaryngology 107: 175 178, 1981

21) Granish MS et al: Fetal rhabdomyoma of the larynx. Archives of Otolaryngology 109 : 821 826, 1983

22) Rosenman $\mathrm{D}$ et al : Rhabdomyoma of the larynx. Journal of Laryngology and Otology $100: 607 \sim 610,1986$

23) Eusebi $V$ et al : Extracardiac rhabdomyoma:a immunocytochemical study and review of the literature. Applied Pathology 6:197 207, 1988

24) Wood GS et al : Adult rhabdomyoma of the larynx. Ear Nose Throat Journal $72: 296 \sim 298$, 1993

25) Selme $\mathrm{V}$ et al : A rare case of dysphonia: Laryngeal rhabdomyoma. Annales de Pathologie $14: 177 \sim 181,1994$

別刷請求先 $=860-8556$ 熊本市本荘 1 丁目 1 番 1 号 熊本大学医学部耳鼻咽喉科学教室 岩谷直美 